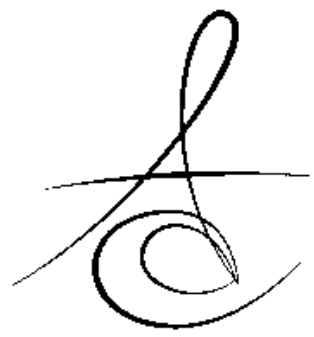

\title{
ASSOCIATION BETWEEN PERI-IMPLANT DISEASES AND CEMENT-RETAINED PROSTHESIS: A REVIEW
}

\section{PERİ-İMPLANT HASTALIKLAR İLE SİMANTE PROTEZLER ARASINDAKİ İLISSKİ: DERLEME}

Yrd. Doç. Dr. Fatih KARAASLAN*

Yrd. Doç. Dr. Mithat TERZí

Makale Kodu/Article code: 2580

Makale Gönderilme tarihi; 01.02.2016

Kabul Tarihi: 18.03.2016

\section{ABSTRACT}

Dental implants are used treatment of partial and total edentulousness. Although implants have long-term success, some problems such as peri-implant diseases can occur around the peri-implant tissues. Peri-implant diseases can considered to result in loss of periimplant bone and osseintegration that effects the long-term succes of dental implants.

Cement-retained restorations are prefered by clinicans because their cementation likes traditional crown cementation. However, cement-retained implant restorations can associate with peri-implant diseases because of involving risk of residual cement. Residual cement in peri-implant mucosa causes bleeding on probing and suppuration, and inflammation can progress the bone then the peri-implant bone loss can occur.

In this review the role of cemented implant restorations in the formation of peri-implant diseases were evaluated and it is tried to explain the impact of

Key Words: cement, peri-implant diseases, cementretained prosthesis residuel cement.

\section{ÖZET}

Dental implantlar parsiyel ve total dişsizliklerin tedavisinde kullanılmaktadır. İmplantlar uzun dönem başarıya sahip olmalarına rağmen, peri-implant hastalıklar gibi bazı problemler gözlenebilir. Periimplant hastalıklarda kemik ile osseointegrasyon kaybı gözlenir ve bu durum implantların uzun dönem başarısını etkilemektedir.

Simante edilen implant restorasyonlar, simantasyon prosedürlerinin geleneksel kronlara benzemesinden dolayı klinisyenler tarafından tercih edilmektedir. Bununla birlikte simante edilen implant restorasyonlar, artık simandan dolayı peri-implant hastalıklara neden olabilmektedir. Artık siman, sondalamada kanama ile süpürasyona neden olabilmekte ve enflamasyonun ilerlemesiyle kemik kaybı meydana gelebilmektedir.

$\mathrm{Bu}$ derlemede simante implant restorasyonların periimplant hastalıkların oluşmasındaki rolü değerlendirilmiş ve artık simanın etkileri anlatılmaya çalışılmıştır.

Anahtar Kelimeler: siman, peri implant hastalıklar, simante protezler

The main predispozing factor in peri-implant

\section{Association Between Peri-implant Diseases and} Cement-Retained Prosthesis: A Review

Dental implants are widely used as an acceptable and predictable treatment options of partial and total edentulous patients. ${ }^{1}$ Although implants have long-term success, have late biological complications like peri-implant diseases. Peri-implant diseases are inflammatory reactions in peri-implant tissues and categorized in two forms; peri-implant mucositis and peri-implantitis. ${ }^{2,3}$ diseases is bacterial colonoziation. ${ }^{4}$ Plaque formation around implants and host response to biofilm formation includes a series of inflammatory reactions. Initially, inflammation is localized to peri-implant mucosa but inflammatory reaction can progress and result in the loss of implant supporting bone. ${ }^{2,5-7}$

\section{Peri-implant Mucositis}

Peri-implant mucositis is similar to gingivitis and presents inflammation around peri-implant soft tissue

\footnotetext{
*Uşak Üniversitesi, Diş Hekimliği Fakültesi, Periodontoloji AD.

** Afyon Kocatepe Üniversitesi, Diş Hekimliği Fakültesi, Periodontoloji AD.
}

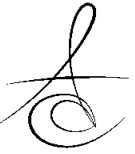


without loss of supporting bone. ${ }^{8}$ Bleeding on probing (BOP), redness, swelling and increased probing depths (4-5 mm) can occur in peri-implant mucositis. ${ }^{5,9}$ The prevalence of peri-implant mucositis has been reported in the range of 8 to $44 \% .{ }^{10}$

Peri-implant mucositis is treated by non-surgical mechanical therapy using carbon fibre to minimize damage to implant surface. Clorhexidine irrigation routinely used as a adjunctive therapy in treatment of peri-implant mucositis. ${ }^{11-14}$

\section{Peri-implantitis}

Peri-implantitis includes soft tissue inflammation and loss of supporting bone, like periodontitis. ${ }^{8}$ Findings from animals and human cross-sectional studies have found that bacterial species associated with periodontitis and peri-implantitis are similar, mainly gram negative aerobes. ${ }^{15,16}$ BOP, deep probing depths ( $>5 \mathrm{~mm}$ ), suppuration can also occur in periimplantitis. The frequency of peri-implantitis has been reported in the range of 1 to $19 \% .{ }^{17}$

Similar to treatment of peri-implant mucositis, non-surgical treatment of peri-implantitis involves the mechanical debridement of plaque from the surface of implant. ${ }^{18}$ There is data that non-surgical treatment fails to eliminate bacterial load and little benefit can be expected in. ${ }^{19}$ Surgical treatment ( access flap, removal of granulation tissue, implant surface decontamination) was shown to give a better outcome. ${ }^{20}$ Local or systemic antibiotics may reduce BOP and probing depths when used in conjuction with surgical traetment. ${ }^{21-24}$

A number of risk factors have been identifed that may lead to the establishment and progression of peri-implant mucositis and peri-implantitis like previous periodontal disease, smoking, poor oral hygiene, genetic factors, poorly controlled diabetes, occlusal overload and residuel cement from cement retained restorations. ${ }^{25}$

\section{Cement-Retained Prosthesis}

Dental implants have grown in popularity, so have the incedence of cemented implant restorations. Clinicians prefer cement-retained prosthesis because of their passive fit, easy control of occlusion, more aesthetic and cementation procedure is similar to tooth. ${ }^{26}$ This is an error, because teeth and implants have very different requirements from each others.
In teeth, supracrestal connective tissue attach to the tooth perpendicularly, resulting in a strong attachment to the tooth. In contrast, the connective tissue attachment in dental implants has fewer fiber bundles and their orientation tends to run parallel to the implant surface, resulting in less protection overall from invading pathogens. ${ }^{27}$ Incomplete removal of cement from peri-implant tissues leaves a nidus of inflammation that can lead to peri-implant disease. The thin junctional epithelium around a dental implant is not a good barrier. As a result, the flow of cement is not restricted and easily migrates apically.

American Academy of Periodontolgy reported that residual cement is a risk factor for peri-implant diseases (peri-implant mucositis and periimplantitis). ${ }^{28}$ The effect of residual cement in periimplant disease can be compared with that dental calculus in periodontal disease. Dental calculus is a predisposing factor due to additional retantion of bacteria and mechanical irritation of periodontal tissues. Cement's rough surface is a good place for bacterial accumulation and biofilm can form on the excess cement. ${ }^{29}$

Wilson ${ }^{30}$ reported that residual cement is one of the predisposing factor for peri-implantitis. In this study, excess cement was associated with signs of peri-implant disease in the majority $(81 \%)$ of the cases. Clinical and endoscopic signs of peri-implant disease were absent in $74 \%$ of the test implants after the removal of excess cement. Korsch et al. ${ }^{31}$ identified residual cement in $59.5 \%$ of implants. BOP was found at $80 \%$ of implants with residual cement and suppuration at $21.3 \%$ of the implants. After removal of excess cement $76.9 \%$ reduction in BOP was found.

Cement-retained prosthesis is associated with peri-implant disease than screw-retained prosthesis. Weber ${ }^{32}$ reported that plaque index and BOP is higher in cement-retained prosthesis than screw-retained ones. Complete removal of excess cement around the implant tissues is unpredictable and the residual cement causes inflammation, bleeding and suppuration. Linkevicius et al. ${ }^{33}$ showed that bonding with cement of implant-supported prostheses resulted in excess cement in peri-implant tissues.

Peri-implant soft tissue response is more positive to screw-retanied prostheses than cementretained prostheses..$^{32}$ Hovewer, some studies showed inflammation in screw-retained prostheses because of 
microgap between restoration and abutment interface. ${ }^{34,35}$ Piattelli et al. $^{36}$ suggested that they showed inflammation around the cement-retained peri-implant tissues because of microgap, compared with cement retained restoration they found no signs of inflammation. Nissan et al. ${ }^{37}$ also reported that cement-retained implant restorations had lower bleeding index and peri-implant bone loss.

Clinicians like to place the margins of their restorations greater than 2-mm subgingival for esthetic reasons. Linkevicius et al and Agar et al reported that removing excess cement around implant restorations with subgingival margins, especially when the margins are greater than $1.5 \mathrm{~mm}$ is impossible. Cement can removed when margins were placed 1$\mathrm{mm}$ supragingival or at the gingival margin. ${ }^{33,38}$

Reducing the amount of used cement can be recommended to minimize the risk of excess cement. The deep subgingival restorations should be avoid because removal of excess cement from this area is very difficult. ${ }^{33}$ Different techniques reported to locate and remove the excess cement such as flap debridement and dental endoscope. ${ }^{30,39}$ High-viscosity cement can prefer to low-viscosity cement because low ones assumed to spread more easily to periimplant tissues. Chee et al. ${ }^{40}$ reported that the least excess cement was present when a cementation device was used. In this study he found no correlation between used cement and excess cement. He also found highest excess cement when cement applied to all axial walls of crown. Using cementation device reduces excess cement significantly. Radiography after cementation can help for better diagnosis of residual cement. Composition of used cement is important to detect the residual cement in radiography. Radiopacity is related with third power of the atomic number of the absorber elements ${ }^{41}$ For this reason zinc found cements like zinc phospote and zinc oxide is detectable in radiography, but acrylic urethane cements are not detectable. However, the location of cement make the radiographic detection of excess cement difficult. Wadhwani ${ }^{42}$ reported that a follow-up radiograph wouldn't have product any result of methacrylate residual cement. In addition residual cement can be seen only in the interproximal gap of cement. In the facial and buccal sides a reliable diagnosis is imposibble because of superposition of implants.

\section{CONCLUSION}

Healthy periodontal tissues are essential for the stability of dentition, likewise healthy peri-implant tissues are essential for stability of dental implant. Biofilm formation plays an important role in initation and progression of peri-implant diseases. Dental calculus is a predisposing factor due to additional retantion of bacteria and mechanical irritation of periodontal tissues. The effect of residual cement in peri-implant diseases can be compared with dental calculus in periodontal diseases. Cement roughness and surface topography supply a good environment for bacterial accumulation. For this reason, detection and removal of residual cement from peri-implant area is helpful in preventing inflammation and peri-implant diseases.

\section{REFERENCES}

1. Aglietta M, Siciliano VI, Zwahlen M, Bragger U, Pjetursson BE, Lang NP, Salvi GE. A systematic review of the survival and complication rates of implant supported fixed dental prostheses with cantilever extensions after an observation period of at least 5 years. Clin Oral Implants Res 2009, 20: 441-51.

2. Mombelli A, Lang NP. The diagnosis and treatment of peri-implantitis. Periodontol 2000 1998, 17: 6376.

3. Lindhe J, Meyle J. Peri-implant diseases: Consensus Report of the Sixth European Workshop on Periodontology. J Clin Periodontol 2008, 35: 282-5.

4. Berglundh T, Lindhe J, Marinello C, Ericsson I, Liljenberg B. Soft tissue reaction to de novo plaque formation on implants and teeth. An experimental study in the dog. Clin Oral Implants Res 1992, 3: $1-8$.

5. Pontoriero R, Tonelli MP, Carnevale G, Mombelli A, Nyman SR, Lang NP. Experimentally induced periimplant mucositis. A clinical study in humans. Clin Oral Implants Res 1994, 5: 254-9.

6. Lang NP, Wilson TG, Corbet EF. Biological complications with dental implants: their prevention, diagnosis and treatment. Clin Oral Implants Res 2000, 11 Suppl 1: 146-55.

7. Albrektsson T, Zarb G, Worthington P, Eriksson AR. The long-term efficacy of currently used dental 
implants: a review and proposed criteria of success. Int J Oral Maxillofac Implants 1986, 1: 11-25.

8. Sanz M, Chapple IL. Clinical research on periimplant diseases: consensus report of Working Group 4. J Clin Periodontol 2012, 39 Suppl 12: 202-6.

9. Salvi GE, Aglietta M, Eick S, Sculean A, Lang NP, Ramseier CA. Reversibility of experimental periimplant mucositis compared with experimental gingivitis in humans. Clin Oral Implants Res 2012, 23: $182-90$.

10. Esposito M, Hirsch JM, Lekholm U, Thomsen P. Biological factors contributing to failures of osseointegrated oral implants. (II). Etiopathogenesis Eur J Oral Sci 1998, 106: 721-64.

11. Trejo PM, Bonaventura G, Weng D, Caffesse RG, Bragger $U$, Lang NP. Effect of mechanical and antiseptic therapy on peri-implant mucositis: an experimental study in monkeys. Clin Oral Implants Res 2006, 17: 294-304.

12. Porras R, Anderson GB, Caffesse R, Narendran S, Trejo PM. Clinical response to 2 different therapeutic regimens to treat peri-implant mucositis. J Periodontol 2002, 73: 1118-25.

13. Maximo MB, de Mendonca AC, Renata Santos V, Figueiredo LC, Feres M, Duarte PM. Short-term clinical and microbiological evaluations of periimplant diseases before and after mechanical antiinfective therapies. Clin Oral Implants Res 2009, 20: 99-108.

14. Strooker H, Rohn S, Van Winkelhoff AJ. Clinical and microbiologic effects of chemical versus mechanical cleansing in professional supportive implant therapy. Int J Oral Maxillofac Implants 1998, 13: 845-50.

15. Nociti FH, Jr., Cesco De Toledo R, Machado MA, Stefani CM, Line SR, Goncalves RB. Clinical and microbiological evaluation of ligature-induced periimplantitis and periodontitis in dogs. Clin Oral Implants Res 2001, 12: 295-300.

16. Heitz-Mayfield LJ, Lang NP. Comparative biology of chronic and aggressive periodontitis vs. periimplantitis. Periodontol 2000, 2010, 53: 167-81.

17. Esposito M, Hirsch JM, Lekholm U, Thomsen P. Biological factors contributing to failures of osseointegrated oral implants. (I). Success criteria and epidemiology. Eur J Oral Sci 1998, 106: 527-
51.

18. Renvert S, Samuelsson E, Lindahl C, Persson GR. Mechanical non-surgical treatment of periimplantitis: a double-blind randomized longitudinal clinical study. I: clinical results. J Clin Periodontol 2009, 36: 604-9.

19. Karring ES, Stavropoulos A, Ellegaard B, Karring T. Treatment of peri-implantitis by the Vector system. Clin Oral Implants Res 2005, 16: 288-93.

20. Renvert S, Polyzois I, Claffey N. Surgical therapy for the control of peri-implantitis. Clin Oral Implants Res 2012, 23 Suppl 6: 84-94.

21. Renvert S, Lessem J, Dahlen G, Lindahl C, Svensson M. Topical minocycline microspheres versus topical chlorhexidine gel as an adjunct to mechanical debridement of incipient peri-implant infections: a randomized clinical trial. J Clin Periodontol 2006, 33: 362-9.

22. Mombelli A, Lang NP. Antimicrobial treatment of peri-implant infections. Clin Oral Implants Res 1992, 3: 162-8.

23. Mombelli A, Feloutzis A, Bragger $U$, Lang NP. Treatment of peri-implantitis by local delivery of tetracycline. Clinical, microbiological and radiological results. Clin Oral Implants Res 2001, 12: 287-94.

24. Buchter A, Meyer U, Kruse-Losler B, Joos U, Kleinheinz J. Sustained release of doxycycline for the treatment of peri-implantitis: randomised controlled trial. Br J Oral Maxillofac Surg, 2004, 42: 439-44.

25. Lang NP, Kinane DF, Lindhe J, Sanz M, Tonetti MS. Sixth European Workshop on Periodontology of the European Academy of Periodontology at the Charterhouse at Ittingen, Thurgau, Switzerland. J Clin Periodontol 2008, 35: 1-2.

26. Keith SE, Miller BH, Woody RD, Higginbottom FL. Marginal discrepancy of screw-retained and cemented metal-ceramic crowns on implants abutments. Int J Oral Maxillofac Implants 1999, 14: 369-78.

27. Wingrove S. (2013) Peri-implant therapy for the dental hygienist: clinical guide to maintenance and disease complications. John Wiley \& Sons I.

28. Peri-implant mucositis and peri-implantitis: a current understanding of their diagnoses and clinical implications. J Periodontol 2013, 84: 43643. 
29. Karaaslan Fatih, Terzi Mithat. Siman artığının neden olduğu peri-implantitis. Atatürk Üniv. Diş Hek. Fak. Derg, 2014, supplement 9: 6-9 .

30. Wilson TG, Jr. The positive relationship between excess cement and peri-implant disease: a prospective clinical endoscopic study. J Periodontol 2009, 80: 1388-92.

31. Korsch M, Obst U, Walther W. Cement-associated peri-implantitis: a retrospective clinical observational study of fixed implant-supported restorations using a methacrylate cement. Clin Oral Implants Res 2014, 25: 797-802.

32. Weber HP, Kim DM, Ng MW, Hwang JW, Fiorellini JP. Peri-implant soft-tissue health surrounding cement- and screw-retained implant restorations: a multi-center, 3-year prospective study. Clin Oral Implants Res 2006, 17: 375-9.

33. Linkevicius $T$, Vindasiute $E$, Puisys A, Peciuliene V. The influence of margin location on the amount of undetected cement excess after delivery of cement-retained implant restorations. Clin Oral Implants Res 2011, 22: 1379-84.

34. Lindhe J, Berglundh $T$. The interface between the mucosa and the implant. Periodontol 2000, 1998, 17: 47-54.

35. Keller W, Bragger U, Mombelli A. Peri-implant microflora of implants with cemented and screw retained suprastructures. Clin Oral Implants Res 1998, 9: 209-17.

36. Piattelli A, Scarano A, Paolantonio M, Assenza B, Leghissa GC, Di Bonaventura G, Catamo G, Piccolomini R. Fluids and microbial penetration in the internal part of cement-retained versus screwretained implant-abutment connections. J Periodontol 2001, 72: 1146-50.

37. Nissan J, Narobai D, Gross O, Ghelfan O, Chaushu G. Long-term outcome of cemented versus screwretained implant-supported partial restorations. Int J Oral Maxillofac Implants 2011, 26: 1102-7.

38. Agar JR, Cameron SM, Hughbanks JC, Parker MH. Cement removal from restorations luted to titanium abutments with simulated subgingival margins. J Prosthet Dent, 1997, 78: 43-7.

39. Dumbrigue HB, Abanomi AA, Cheng LL. Techniques to minimize excess luting agent in cement-retained implant restorations. J Prosthet Dent, 2002, 87: 112-4.
40. Chee WW, Duncan J, Afshar M, Moshaverinia A. Evaluation of the amount of excess cement around the margins of cement-retained dental implant restorations: the effect of the cement application method. J Prosthet Dent, 2013, 109: 216-21.

41. White SC, Pharoah MJ. Oral radiology: principles and interpretation. 6th ed: St. Louis: Elsevier; 2009. p. $14,152-3$.

42. Wadhwani $C$, Hess T, Faber T, Pineyro A, Chen CS. A descriptive study of the radiographic density of implant restorative cements. J Prosthet Dent, 2010, 103: 295-302.

\section{Yazışma Adresi}

Yrd. Doç. Dr. Fatih KARAASLAN

Uşak Üniversitesi

Diş Hekimliği Fakültesi

Periodontoloji Anabilim Dalı

e-mail: fatih.karaaslan@usak.edu.tr 